\title{
Phosphodiesterases, 3',5'-cyclic nucleotide (PDEs) in GtoPdb v.2021.3
}

Chen Yan $^{1}$

1. University of Rochester, USA

\begin{abstract}
3',5'-Cyclic nucleotide phosphodiesterases (PDEs, 3',5'-cyclic-nucleotide 5'-nucleotidohydrolase), E.C. 3.1.4.17, catalyse the hydrolysis of a 3',5'-cyclic nucleotide (usually cyclic AMP or cyclic GMP). isobutylmethylxanthine is a nonselective inhibitor with an $\mathrm{IC}_{50}$ value in the millimolar range for all isoforms except PDE 8A, 8B and 9A. A 2',3'-cyclic nucleotide 3'-phosphodiesterase (E.C. 3.1.4.37 CNPase) activity is associated with myelin formation in the development of the CNS.
\end{abstract}

\section{Contents}

This is a citation summary for Phosphodiesterases, 3',5'-cyclic nucleotide (PDEs) in the Guide to Pharmacology database (GtoPdb). It exists purely as an adjunct to the database to facilitate the recognition of citations to and from the database by citation analyzers. Readers will almost certainly want to visit the relevant sections of the database which are given here under database links.

GtoPdb is an expert-driven guide to pharmacological targets and the substances that act on them. GtoPdb is a reference work which is most usefully represented as an on-line database. As in any publication this work should be appropriately cited, and the papers it cites should also be recognized. This document provides a citation for the relevant parts of the database, and also provides a reference list for the research cited by those parts. For further details see [12].

Please note that the database version for the citations given in GtoPdb are to the most recent preceding version in which the family or its subfamilies and targets were substantially changed. The links below are to the current version. If you need to consult the cited version, rather than the most recent version, please contact the GtoPdb curators.

\section{Database links}

Phosphodiesterases, 3',5'-cyclic nucleotide (PDEs)

https://www.guidetopharmacology.org/GRAC/FamilyDisplayForward?familyId=260

Introduction to Phosphodiesterases, 3',5'-cyclic nucleotide (PDEs)

https://www.guidetopharmacology.org/GRAC/FamilyIntroductionForward?familyId=260

Enzymes

PDE1A(phosphodiesterase 1A)

https://www.guidetopharmacology.org/GRAC/ObjectDisplayForward?objectId=1294 PDE1B(phosphodiesterase 1B)

https://www.guidetopharmacology.org/GRAC/ObjectDisplayForward?objectId=1295 PDE1C(phosphodiesterase 1C)

https://www.guidetopharmacology.org/GRAC/ObjectDisplayForward?objectId=1296 PDE2A(phosphodiesterase 2A)

https://www.guidetopharmacology.org/GRAC/ObjectDisplayForward?objectId=1297 PDE3A(phosphodiesterase 3A)

https://www.guidetopharmacology.org/GRAC/ObjectDisplayForward?objectId=1298 PDE3B(phosphodiesterase 3B)

https://www.guidetopharmacology.org/GRAC/ObjectDisplayForward?objectId=1299 PDE4A(phosphodiesterase 4A)

https://www.guidetopharmacology.org/GRAC/ObjectDisplayForward?objectId=1300 PDE4B(phosphodiesterase 4B)

https://www.guidetopharmacology.org/GRAC/ObjectDisplayForward?objectId=1301 
PDE4C(phosphodiesterase 4C)

https://www.guidetopharmacology.org/GRAC/ObjectDisplayForward?objectId=1302 PDE4D(phosphodiesterase 4D)

https://www.guidetopharmacology.org/GRAC/ObjectDisplayForward?objectId=1303 PDE5A(phosphodiesterase 5A)

https://www.guidetopharmacology.org/GRAC/ObjectDisplayForward?objectId=1304 PDE6A(phosphodiesterase 6A)

https://www.guidetopharmacology.org/GRAC/ObjectDisplayForward?objectId=1312 PDE6B(phosphodiesterase 6B)

https://www.guidetopharmacology.org/GRAC/ObjectDisplayForward?objectId=1313 PDE6C(phosphodiesterase 6C)

https://www.guidetopharmacology.org/GRAC/ObjectDisplayForward?objectId=1314 PDE6D(phosphodiesterase 6D)

https://www.guidetopharmacology.org/GRAC/ObjectDisplayForward?objectId=1315 PDE6G(phosphodiesterase 6G)

https://www.guidetopharmacology.org/GRAC/ObjectDisplayForward?objectId=1316 PDE6H(phosphodiesterase 6H)

https://www.guidetopharmacology.org/GRAC/ObjectDisplayForward?objectId=1317 PDE7A(phosphodiesterase 7A)

https://www.guidetopharmacology.org/GRAC/ObjectDisplayForward?objectId=1305 PDE7B(phosphodiesterase 7B)

https://www.guidetopharmacology.org/GRAC/ObjectDisplayForward?objectId=1306 PDE8A(phosphodiesterase 8A)

https://www.guidetopharmacology.org/GRAC/ObjectDisplayForward?objectId=1307 PDE8B(phosphodiesterase 8B)

https://www.guidetopharmacology.org/GRAC/ObjectDisplayForward?objectId=1308 PDE9A(phosphodiesterase 9A)

https://www.guidetopharmacology.org/GRAC/ObjectDisplayForward?objectId=1309 PDE10A(phosphodiesterase 10A)

https://www.guidetopharmacology.org/GRAC/ObjectDisplayForward?objectId=1310 PDE11A(phosphodiesterase 11A)

https://www.guidetopharmacology.org/GRAC/ObjectDisplayForward?objectId=1311

\section{References}

1. Adams JL, Smothers J, Srinivasan R and Hoos A. (2015) Big opportunities for small molecules in immuno-oncology. Nat Rev Drug Discov 14: 603-22 [PMID:26228631]

2. Akama T, Baker SJ, Zhang YK, Hernandez V, Zhou H, Sanders V, Freund Y, Kimura R, Maples KR and Plattner JJ. (2009) Discovery and structure-activity study of a novel benzoxaborole antiinflammatory agent (AN2728) for the potential topical treatment of psoriasis and atopic dermatitis. Bioorg Med Chem Lett 19: 2129-32 [PMID:19303290]

3. Alaamery MA, Wyman AR, Ivey FD, Allain C, Demirbas D, Wang L, Ceyhan O and Hoffman CS. (2010) New classes of PDE7 inhibitors identified by a fission yeast-based HTS. J Biomol Screen 15: 359-67 [PMID:20228279]

4. Albrecht W, Unger A, Bauer SM and Laufer SA. (2017) Discovery of N-\{4-[5-(4-Fluorophenyl)-3methyl-2-methylsulfanyl-3H-imidazol-4-yl]-pyridin-2-yl $\}$-acetamide (CBS-3595), a Dual p38 $\alpha$ MAPK/PDE-4 Inhibitor with Activity against TNF $\alpha$-Related Diseases. J Med Chem 60: 5290-5305 [PMID:28613871]

5. Allcock RW, Blakli H, Jiang Z, Johnston KA, Morgan KM, Rosair GM, Iwase K, Kohno Y and Adams DR. (2011) Phosphodiesterase inhibitors. Part 1: Synthesis and structure-activity relationships of pyrazolopyridine-pyridazinone PDE inhibitors developed from ibudilast. Bioorg Med Chem Lett 21: 3307-12 [PMID:21530250]

6. Aoki M, Kobayashi M, Ishikawa J, Saita Y, Terai Y, Takayama K, Miyata K and Yamada T. (2000) A novel phosphodiesterase type 4 inhibitor, YM976 (4-(3-chlorophenyl)-1,7-diethylpyrido[2,3d]pyrimidin-2(1H)-one), with little emetogenic activity. J Pharmacol Exp Ther 295: 255-60 [PMID:10991987]

7. Ashton MJ, Cook DC, Fenton G, Karlsson JA, Palfreyman MN, Raeburn D, Ratcliffe AJ, Souness JE, Thurairatnam S and Vicker N. (1994) Selective type IV phosphodiesterase inhibitors as antiasthmatic agents. The syntheses and biological activities of 3-(cyclopentyloxy)-4methoxybenzamides and analogues. J Med Chem 37: 1696-703 [PMID:8201604]

8. Basole CP, Nguyen RK, Lamothe K, Vang A, Clark R, Baillie GS, Epstein PM and Brocke S. (2017) PDE8 controls CD4 ${ }^{+}$T cell motility through the PDE8A-Raf-1 kinase signaling complex. Cell Signal 40: 62-72 [PMID:28851628]

9. Boess FG, Hendrix M, van der Staay FJ, Erb C, Schreiber R, van Staveren W, de Vente J, Prickaerts J, Blokland A and Koenig G. (2004) Inhibition of phosphodiesterase 2 increases neuronal cGMP, synaptic plasticity and memory performance. Neuropharmacology 47: 1081-92 
[PMID:15555642]

10. Boyle CD, Xu R, Asberom T, Chackalamannil S, Clader JW, Greenlee WJ, Guzik H, Hu Y, Hu Z and Lankin CM et al.. (2005) Optimization of purine based PDE1/PDE5 inhibitors to a potent and selective PDE5 inhibitor for the treatment of male ED. Bioorg Med Chem Lett 15: 2365-9 [PMID:15837326]

11. Bridgewood C, Damiani G, Sharif K, Watad A, Bragazzi NL, Quartuccio L, Savic S and McGonagle D. (2020) Rationale for Evaluating PDE4 Inhibition for Mitigating against Severe Inflammation in COVID-19 Pneumonia and Beyond. Isr Med Assoc J 22: 335-339 [PMID:32558435]

12. Buneman P, Christie G, Davies JA, Dimitrellou R, Harding SD, Pawson AJ, Sharman JL and Wu Y. (2020) Why data citation isn't working, and what to do about it Database 2020 [PMID:32367113]

13. Ceyhan O, Birsoy K and Hoffman CS. (2012) Identification of biologically active PDE11-selective inhibitors using a yeast-based high-throughput screen. Chem Biol 19: 155-63 [PMID:22284362]

14. Clerin V, Gale J and Tamimi N.. (2014) Use of a tetrasubstituted pyrazolo[4,3-d]pyrimidine compound for treating diabetic nephropathy. Patent number: WO-2014064566-A1.

15. Corbin JD, Turko IV, Beasley A and Francis SH. (2000) Phosphorylation of phosphodiesterase-5 by cyclic nucleotide-dependent protein kinase alters its catalytic and allosteric cGMP-binding activities. Eur J Biochem 267: 2760-7 [PMID:10785399]

16. Dalamaga M, Karampela I and Mantzoros CS. (2020) Commentary: Phosphodiesterase 4 inhibitors as potential adjunct treatment targeting the cytokine storm in COVID-19. Metabolism 109: 154282 [PMID:32497535]

17. Doh H, Shin CY, Son M, Ko JI, Yoo M, Kim SH and Kim WB. (2002) Mechanism of erectogenic effect of the selective phosphodiesterase type 5 inhibitor, DA-8159. Arch Pharm Res 25: 873-8 [PMID:12510841]

18. Edmondson SD, Mastracchio A, He J, Chung CC, Forrest MJ, Hofsess S, MacIntyre E, Metzger J, O'Connor N and Patel K et al.. (2003) Benzyl vinylogous amide substituted aryldihydropyridazinones and aryldimethylpyrazolones as potent and selective PDE3B inhibitors. Bioorg Med Chem Lett 13: 3983-7 [PMID:14592490]

19. Fawcett L, Baxendale R, Stacey P, McGrouther C, Harrow I, Soderling S, Hetman J, Beavo JA and Phillips SC. (2000) Molecular cloning and characterization of a distinct human phosphodiesterase gene family: PDE11A. Proc Natl Acad Sci USA 97: 3702-7 [PMID:10725373]

20. Fisher DA, Smith JF, Pillar JS, St Denis SH and Cheng JB. (1998) Isolation and characterization of PDE8A, a novel human cAMP-specific phosphodiesterase. Biochem Biophys Res Commun 246: 570-7 [PMID:9618252]

21. Fisher DA, Smith JF, Pillar JS, St Denis SH and Cheng JB. (1998) Isolation and characterization of PDE9A, a novel human cGMP-specific phosphodiesterase. J Biol Chem 273: 15559-64 [PMID:9624146]

22. Fujishige K, Kotera J, Michibata H, Yuasa K, Takebayashi S, Okumura K and Omori K. (1999) Cloning and characterization of a novel human phosphodiesterase that hydrolyzes both cAMP and cGMP (PDE10A). J Biol Chem 274: 18438-45 [PMID:10373451]

23. Gao J, Long L, Xu F, Feng L, Liu Y, Shi J and Gong Q. (2020) Icariside II, a phosphodiesterase 5 inhibitor, attenuates cerebral ischaemia/reperfusion injury by inhibiting glycogen synthase kinase-3ß-mediated activation of autophagy. Br J Pharmacol 177: 1434-1452 [PMID:31658364]

24. Gardner C, Robas N, Cawkill D and Fidock M. (2000) Cloning and characterization of the human and mouse PDE7B, a novel cAMP-specific cyclic nucleotide phosphodiesterase. Biochem Biophys Res Commun 272: 186-92 [PMID:10872825]

25. Gharat LA, Gopalan B and Khairatkar-Joshi N. (2006) Novel heterocyclic compounds useful for the treatment of inflammatory and allergic disorders. Patent number: WO2006064355A2.

26. Giembycz MA. (2008) Can the anti-inflammatory potential of PDE4 inhibitors be realized: guarded optimism or wishful thinking? Br J Pharmacol 155: 288-90 [PMID:18660832]

27. Giembycz MA and Newton R. (2011) Harnessing the clinical efficacy of phosphodiesterase 4 inhibitors in inflammatory lung diseases: dual-selective phosphodiesterase inhibitors and novel combination therapies. Handb Exp Pharmacol: 415-46 [PMID:21695651]

28. Guay D, Boulet L, Friesen RW, Girard M, Hamel P, Huang Z, Laliberté F, Laliberté S, Mancini JA and Muise E et al.. (2008) Optimization and structure-activity relationship of a series of 1phenyl-1,8-naphthyridin-4-one-3-carboxamides: identification of MK-0873, a potent and effective PDE4 inhibitor. Bioorg Med Chem Lett 18: 5554-8 [PMID:18835163]

29. Gurney ME, Nugent RA, Mo X, Sindac JA, Hagen TJ, Fox 3rd D, O'Donnell JM, Zhang C, Xu Y and Zhang HT et al.. (2019) Design and Synthesis of Selective Phosphodiesterase 4D (PDE4D) Allosteric Inhibitors for the Treatment of Fragile X Syndrome and Other Brain Disorders. J Med Chem 62: 4884-4901 [PMID:31013090]

30. Hanifin JM, Ellis CN, Frieden IJ, Fölster-Holst R, Stein Gold LF, Secci A, Smith AJ, Zhao C, Kornyeyeva E and Eichenfield LF. (2016) OPA-15406, a novel, topical, nonsteroidal, selective phosphodiesterase-4 (PDE4) inhibitor, in the treatment of adult and adolescent patients with mild to moderate atopic dermatitis $(\mathrm{AD})$ : A phase-II randomized, double-blind, placebo- 
controlled study. J Am Acad Dermatol 75: 297-305 [PMID:27189825]

31. Hayashi M, Matsushima K, Ohashi H, Tsunoda H, Murase S, Kawarada Y and Tanaka T. (1998) Molecular cloning and characterization of human PDE8B, a novel thyroid-specific isozyme of 3', 5'-cyclic nucleotide phosphodiesterase. Biochem Biophys Res Commun 250: 751-6 [PMID:9784418]

32. Helal CJ, Arnold E, Boyden T, Chang C, Chappie TA, Fisher E, Hajos M, Harms JF, Hoffman WE and Humphrey JM et al.. (2018) Identification of a Potent, Highly Selective, and Brain Penetrant Phosphodiesterase 2A Inhibitor Clinical Candidate. J Med Chem 61: 1001-1018 [PMID:29293004]

33. Hoffmann R, Baillie GS, MacKenzie SJ, Yarwood SJ and Houslay MD. (1999) The MAP kinase ERK2 inhibits the cyclic AMP-specific phosphodiesterase HSPDE4D3 by phosphorylating it at Ser579. EMBO J 18: 893-903 [PMID:10022832]

34. Hoffmann R, Wilkinson IR, McCallum JF, Engels P and Houslay MD. (1998) cAMP-specific phosphodiesterase HSPDE4D3 mutants which mimic activation and changes in rolipram inhibition triggered by protein kinase A phosphorylation of Ser-54: generation of a molecular model. Biochem J 333 ( Pt 1): 139-49 [PMID:9639573]

35. Houslay MD and Adams DR. (2003) PDE4 cAMP phosphodiesterases: modular enzymes that orchestrate signalling cross-talk, desensitization and compartmentalization. Biochem J 370: 118 [PMID:12444918]

36. Huang Z, Dias R, Jones T, Liu S, Styhler A, Claveau D, Otu F, Ng K, Laliberte F and Zhang L et al.. (2007) L-454,560, a potent and selective PDE4 inhibitor with in vivo efficacy in animal models of asthma and cognition. Biochem Pharmacol 73: 1971-81 [PMID:17428447]

37. Hughes RO, Walker JK, Rogier DJ, Heasley SE, Blevis-Bal RM, Benson AG, Jacobsen EJ, Cubbage JW, Fobian YM and Owen DR et al.. (2009) Optimization of the aminopyridopyrazinones class of PDE5 inhibitors: discovery of 3-[(trans-4-hydroxycyclohexyl)amino]-7-(6-methoxypyridin-3-yl)-1(2-propoxyethyl)pyrido[3,4-b]pyrazin-2(1H)-one. Bioorg Med Chem Lett 19: 5209-13 [PMID:19631533]

38. Jones GH, Venuti MC, Alvarez R, Bruno JJ, Berks AH and Prince A. (1987) Inhibitors of cyclic AMP phosphodiesterase. 1. Analogues of cilostamide and anagrelide. J Med Chem 30: 295-303 [PMID:3027338]

39. Keshavarzian A, Mutlu E, Guzman JP, Forsyth C and Banan A. (2007) Phosphodiesterase 4 inhibitors and inflammatory bowel disease: emerging therapies in inflammatory bowel disease. Expert Opin Investig Drugs 16: 1489-506 [PMID:17714033]

40. Kodimuthali A, Jabaris SS and Pal M. (2008) Recent advances on phosphodiesterase 4 inhibitors for the treatment of asthma and chronic obstructive pulmonary disease. J Med Chem 51: 547189 [PMID:18686943]

41. Korkmaz-Icöz S, Radovits T and Szabó G. (2018) Targeting phosphodiesterase 5 as a therapeutic option against myocardial ischaemia/reperfusion injury and for treating heart failure. $\mathrm{BrJ}$ Pharmacol 175: 223-231 [PMID:28213937]

42. Loughney K, Martins TJ, Harris EA, Sadhu K, Hicks JB, Sonnenburg WK, Beavo JA and Ferguson $\mathrm{K}$. (1996) Isolation and characterization of cDNAs corresponding to two human calcium, calmodulin-regulated, 3',5'-cyclic nucleotide phosphodiesterases. J Biol Chem 271: 796-806 [PMID:8557689]

43. Lunniss CJ, Cooper AW, Eldred CD, Kranz M, Lindvall M, Lucas FS, Neu M, Preston AG, Ranshaw LE and Redgrave AJ et al.. (2009) Quinolines as a novel structural class of potent and selective PDE4 inhibitors: optimisation for oral administration. Bioorg Med Chem Lett 19: 13805 [PMID:19195882]

44. Malamas MS, Ni Y, Erdei J, Stange H, Schindler R, Lankau HJ, Grunwald C, Fan KY, Parris K and Langen B et al.. (2011) Highly potent, selective, and orally active phosphodiesterase 10A inhibitors. J Med Chem 54: 7621-38 [PMID:21988093]

45. Martinez GR, Walker KA, Hirschfeld DR, Bruno JJ, Yang DS and Maloney PJ. (1992) 3,4Dihydroquinolin-2 $(1 \mathrm{H})$-ones as combined inhibitors of thromboxane A2 synthase and cAMP phosphodiesterase. J Med Chem 35: 620-8 [PMID:1311763]

46. Maurice DH, Ke H, Ahmad F, Wang Y, Chung J and Manganiello VC. (2014) Advances in targeting cyclic nucleotide phosphodiesterases. Nat Rev Drug Discov 13: 290-314 [PMID:24687066]

47. Meanwell NA, Pearce BC, Roth HR, Smith EC, Wedding DL, Wright JJ, Buchanan JO, Baryla UM, Gamberdella M and Gillespie E et al.. (1992) Inhibitors of blood platelet cAMP phosphodiesterase. 2. Structure-activity relationships associated with 1,3-dihydro-2Himidazo[4,5-b]quinolin-2-ones substituted with functionalized side chains. J Med Chem 35: 267287 [PMID:1321910]

48. Michaeli T, Bloom TJ, Martins T, Loughney K, Ferguson K, Riggs M, Rodgers L, Beavo JA and Wigler M. (1993) Isolation and characterization of a previously undetected human cAMP phosphodiesterase by complementation of cAMP phosphodiesterase-deficient Saccharomyces cerevisiae. J Biol Chem 268: 12925-32 [PMID:8389765]

49. Michie AM, Lobban M, Müller T, Harnett MM and Houslay MD. (1996) Rapid regulation of PDE- 
2 and PDE-4 cyclic AMP phosphodiesterase activity following ligation of the T cell antigen receptor on thymocytes: analysis using the selective inhibitors erythro-9-(2-hydroxy-3-nonyl)adenine (EHNA) and rolipram. Cell Signal 8: 97-110 [PMID:8730511]

50. Mochida H, Takagi M, Inoue H, Noto T, Yano K, Fujishige K, Sasaki T, Yuasa K, Kotera J and Omori K et al.. (2002) Enzymological and pharmacological profile of T-0156, a potent and selective phosphodiesterase type 5 inhibitor. Eur J Pharmacol 456: 91-8 [PMID:12450574]

51. Mohamed HA, Girgis NM, Wilcken R, Bauer MR, Tinsley HN, Gary BD, Piazza GA, Boeckler FM and Abadi AH. (2011) Synthesis and molecular modeling of novel tetrahydro- $\beta$-carboline derivatives with phosphodiesterase 5 inhibitory and anticancer properties. J Med Chem 54: 495509 [PMID:21189023]

52. Moslin R, Gardner D, Santella J, Zhang Y, Duncia JV, Liu C, Lin J, Tokarski JS, Strnad J and Pedicord D et al.. (2017) Identification of imidazo[1,2-b]pyridazine TYK2 pseudokinase ligands as potent and selective allosteric inhibitors of TYK2 signalling. Medchemcomm 8: 700-712 [PMID:30108788]

53. Mulhall AM, Droege CA, Ernst NE, Panos RJ and Zafar MA. (2015) Phosphodiesterase 4 inhibitors for the treatment of chronic obstructive pulmonary disease: a review of current and developing drugs. Expert Opin Investig Drugs 24: 1597-611 [PMID:26419847]

54. Okada M, Kato M, Sato N, Uno T, Kitagaki H, Haruta J, Hiyama H and Shibata T. (2007) Oxazole compound and pharmaceutical composition Patent number: WO2007058338.

55. Perry MJ, O'Connell J, Walker C, Crabbe T, Baldock D, Russell A, Lumb S, Huang Z, Howat D and Allen R et al.. (1998) CDP840: a novel inhibitor of PDE-4. Cell Biochem Biophys 29: 113-32 [PMID:9631241]

56. Porteous DJ, Millar JK, Brandon NJ and Sawa A. (2011) DISC1 at 10: connecting psychiatric genetics and neuroscience. Trends Mol Med 17: 699-706 [PMID:22015021]

57. Rawson DJ, Ballard S, Barber C, Barker L, Beaumont K, Bunnage M, Cole S, Corless M, Denton S and Ellis D et al.. (2012) The discovery of UK-369003, a novel PDE5 inhibitor with the potential for oral bioavailability and dose-proportional pharmacokinetics. Bioorg Med Chem 20: 498-509 [PMID:22100260]

58. Salari-Sharif P and Abdollahi M. (2010) Phosphodiesterase 4 inhibitors in inflammatory bowel disease: a comprehensive review. Curr Pharm Des 16: 3661-7 [PMID:21128899]

59. Saldou N, Obernolte R, Huber A, Baecker PA, Wilhelm R, Alvarez R, Li B, Xia L, Callan O and Su $\mathrm{C}$ et al.. (1998) Comparison of recombinant human PDE4 isoforms: interaction with substrate and inhibitors. Cell Signal 10: 427-40 [PMID:9720765]

60. Sasaki T, Kotera J, Yuasa K and Omori K. (2000) Identification of human PDE7B, a cAMP-specific phosphodiesterase. Biochem Biophys Res Commun 271: 575-83 [PMID:10814504]

61. Schafer PH, Parton A, Capone L, Cedzik D, Brady H, Evans JF, Man HW, Muller GW, Stirling DI and Chopra R. (2014) Apremilast is a selective PDE4 inhibitor with regulatory effects on innate immunity. Cell Signal 26: 2016-29 [PMID:24882690]

62. Sircar I, Steffen RP, Bobowski G, Burke SE, Newton RS, Weishaar RE, Bristol JA and Evans DB. (1989) Cardiotonic agents. 9. Synthesis and biological evaluation of a series of (E)-4,5-dihydro-6[2-[4-(1H-imidazol-1-yl)phenyl]ethenyl]-3 (2H)-pyridazinones: a novel class of compounds with positive inotropic, antithrombotic, and vasodilatory activities for the treatment of congestive heart failure. J Med Chem 32: 342-50 [PMID:2536438]

63. Smith SJ, Cieslinski LB, Newton R, Donnelly LE, Fenwick PS, Nicholson AG, Barnes PJ, Barnette MS and Giembycz MA. (2004) Discovery of BRL 50481 [3-(N,N-dimethylsulfonamido)-4-methylnitrobenzene], a selective inhibitor of phosphodiesterase 7: in vitro studies in human monocytes, lung macrophages, and CD8+ T-lymphocytes. Mol Pharmacol 66: 1679-89 [PMID:15371556]

64. Sudo T, Tachibana K, Toga K, Tochizawa S, Inoue Y, Kimura Y and Hidaka H. (2000) Potent effects of novel anti-platelet aggregatory cilostamide analogues on recombinant cyclic nucleotide phosphodiesterase isozyme activity. Biochem Pharmacol 59: 347-56 [PMID:10644042]

65. Torphy TJ and Undem BJ. (1991) Phosphodiesterase inhibitors: new opportunities for the treatment of asthma. Thorax 46: 512-23 [PMID:1877039]

66. Tsai YF, Chu TC, Chang WY, Wu YC, Chang FR, Yang SC, Wu TY, Hsu YM, Chen CY and Chang SH et al.. (2017) 6-Hydroxy-5,7-dimethoxy-flavone suppresses the neutrophil respiratory burst via selective PDE4 inhibition to ameliorate acute lung injury. Free Radic Biol Med 106: 379-392 [PMID:28263828]

67. Turko IV, Ballard SA, Francis SH and Corbin JD. (1999) Inhibition of cyclic GMP-binding cyclic GMP-specific phosphodiesterase (Type 5) by sildenafil and related compounds. Mol Pharmacol 56: 124-30 [PMID:10385692]

68. Vemulapalli S, Watkins RW, Chintala M, Davis H, Ahn HS, Fawzi A, Tulshian D, Chiu P, Chatterjee M and Lin CC et al.. (1996) Antiplatelet and antiproliferative effects of SCH 51866, a novel type 1 and type 5 phosphodiesterase inhibitor. J Cardiovasc Pharmacol 28: 862-9 [PMID:8961086]

69. Venhuis BJ, Zomer G, Hamzink M, Meiring HD, Aubin Y and de Kaste D. (2011) The identification of a nitrosated prodrug of the PDE-5 inhibitor aildenafil in a dietary supplement: a 
Viagra with a pop. J Pharm Biomed Anal 54: 735-41 [PMID:21145686]

70. Venuti MC, Jones GH, Alvarez R and Bruno JJ. (1987) Inhibitors of cyclic AMP

phosphodiesterase. 2. Structural variations of N-cyclohexyl-N-methyl-4-[(1,2,3,5-tetrahydro- 2oxoimidazo[2,1-b]quinazolin-7-yl)-oxy]butyramide (RS-82856). J Med Chem 30: 303-18 [PMID:3027339]

71. Verhoest PR, Chapin DS, Corman M, Fonseca K, Harms JF, Hou X, Marr ES, Menniti FS, Nelson F and O'Connor R et al.. (2009) Discovery of a novel class of phosphodiesterase 10A inhibitors and identification of clinical candidate 2-[4-(1-methyl-4-pyridin-4-yl-1H-pyrazol-3-yl)phenoxymethyl]-quinoline (PF-2545920) for the treatment of schizophrenia. J Med Chem 52: 5188-96 [PMID:19630403]

72. Wang G, Liu Z, Chen T, Wang Z, Yang H, Zheng M, Ren J, Tian G, Yang X and Li L et al.. (2012) Design, synthesis, and pharmacological evaluation of monocyclic pyrimidinones as novel inhibitors of PDE5. J Med Chem 55: 10540-50 [PMID:23137303]

73. Wang P, Myers JG, Wu P, Cheewatrakoolpong B, Egan RW and Billah MM. (1997) Expression, purification, and characterization of human cAMP-specific phosphodiesterase (PDE4) subtypes A, B, C, and D. Biochem Biophys Res Commun 234: 320-4 [PMID:9177268]

74. Wang P, Wu P, Ohleth KM, Egan RW and Billah MM. (1999) Phosphodiesterase 4B2 is the predominant phosphodiesterase species and undergoes differential regulation of gene expression in human monocytes and neutrophils. Mol Pharmacol 56: 170-4 [PMID:10385698]

75. Wilson LS and Brandon NJ. (2015) Emerging biology of PDE10A. Curr Pharm Des 21: 378-88 [PMID:25159072]

76. Wu Y, Tian YJ, Le ML, Zhang SR, Zhang C, Huang MX, Jiang MY, Zhang B and Luo HB. (2020) Discovery of Novel Selective and Orally Bioavailable Phosphodiesterase-1 Inhibitors for the Efficient Treatment of Idiopathic Pulmonary Fibrosis. J Med Chem 63: 7867-7879 [PMID:32603117]

77. Yang SW, Smotryski J, McElroy WT, Tan Z, Ho G, Tulshian D, Greenlee WJ, Guzzi M, Zhang X and Mullins D et al.. (2012) Discovery of orally active pyrazoloquinolines as potent PDE10 inhibitors for the management of schizophrenia. Bioorg Med Chem Lett 22: 235-9 [PMID:22142545]

78. You T, Cheng Y, Zhong J, Bi B, Zeng B, Zheng W, Wang H and Xu J. (2017) Roflupram, a Phosphodiesterase 4 Inhibitior, Suppresses Inflammasome Activation through Autophagy in Microglial Cells. ACS Chem Neurosci 8: 2381-2392 [PMID:28605578]

79. Zhang X, Dong G, Li H, Chen W, Li J, Feng C, Gu Z, Zhu F, Zhang R and Li M et al.. (2019) Structure-Aided Identification and Optimization of Tetrahydro-isoquinolines as Novel PDE4 Inhibitors Leading to Discovery of an Effective Antipsoriasis Agent. J Med Chem 62: 5579-5593 [PMID:31099559] 